\title{
ICE FORMATIONS MONITORING AND INTERVENTION ON THE RIVERS IN ROMANIA IN JANUARY-FEBRUARY 2017
}

\author{
I.S. RÎNDAŞU-BEURAN ${ }^{1}$, R. D. BOGZIANU ${ }^{1}$, S. NACU ${ }^{1}$, A. C. MOLDOVAN", \\ R. OBREJA ${ }^{3}$, B. G. PITICARI ${ }^{4}$
}

\begin{abstract}
Ice Formations Monitoring and intervention on the rivers in Romania in January-February 2017. This article presents ice monitoring and intervention on the rivers in Romania in January-February, 2017. After a long period in January with very low temperatures, there were positive temperatures with significant rainfall in the first decade, causing ice flows followed by ice jams and floods. In order to reduce the damage done by overflowing rivers "Romanian Waters" National Administration employees from Alba, Bistrița-Năsăud, Brașov, Covasna, Harghita, Maramureș, Mureș and Suceava counties participated in the operation. Pyrotechnics teams from County Inspectorate for Emergency Situations intervened in the following counties: Alba, Bistrița-Năsăud, Maramureș, Mureș, Suceava and Vâlcea counties. There has been reported damages in Alba, Bistriţa-Năsăud, Botoşani, Harghita, Hunedoara, Iaşi, Maramureş, Mureş and Suceava. The most affected county was Bistriţa-Năsăud, the most pyrotechnical interventions occurred in Suceava. The intervention with special pyrotechnical equipment makes damage insignificant as it happened in Braşov, Covasna and Vâlcea counties. (Fig. 1).
\end{abstract}

Key words: ice phenomena, hydro-meteorological conditions, ice monitoring, ice flows

\section{INTRODUCTION}

Floods resulted from ice-flows are phenomena caused both by torrential or long lasting rain and crowding floes of ice in the narrow area of riverbeds. When there are high snow layer in watershed, followed by a significant rainfall and the river is frozen, devastating floods can occur due to breaking the ice bridge. Ice resulting from breaking the ice bridge floats on the river, when getting to narrow river beds thus forming ice flows (Pisota, 1995). Behind the blockage water gathers in and overflows pressing the river shores.

River flooding is most frequently caused by flash-floods in Romania. They usually occur in spring when snow melts, frequently overlapped by rain (Şelărescu, 1993), although there are cases when they occur in winter as it happened last year.

\footnotetext{
1 "Romanian Waters" National Administration, Bucharest,e-mail: sorin.randasu@rowater.ro, razvan.bogzianu@rowater.ro,simion.nacu@rowater.ro

${ }^{2}$ Someş-Tisa Water Basin Administration, Water Management System Bistrița-Năsăud, Bistriţa, email: cosmin.moldovan@sgabn.dast.rowater.ro

${ }^{3}$ Water Basin Administration Mureș, Târgu Mureş, e-mail: razvan.obreja@dam.rowater.ro

${ }^{4}$ Water Basin Administration Siret, Water Management System Suceava, Câmpulung Moldovenesc Team, Câmpulung Moldovenesc, e-mail: campulung@sgasv.das.rowater.ro
} 


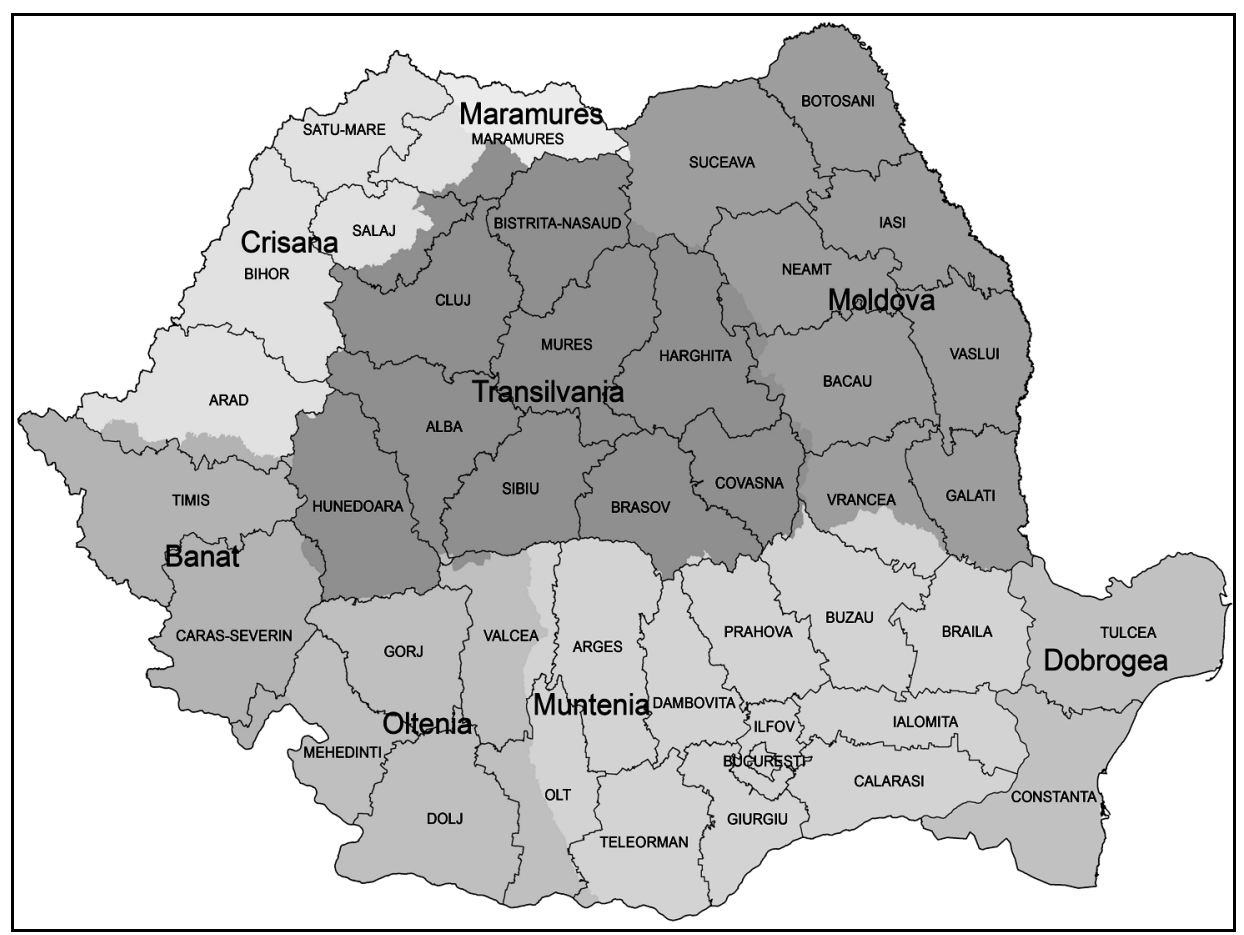

Fig. 1. Romanian regions and counties

Ice blocks reaching the main riverbed destroy almost everything on the way (Stănescu 2012). Protection against ice flows can be done in three steps:

- $\quad$ Step one when ice starts to fall off and drain on the stream.

- $\quad$ Step two when the draining ice starts to form clumps.

- Step three when the ice is blocked in streams (Governmental Decree 1422/192 from 2012).

To reduce ice-flows destructive effect one must intervene either by detonating the ice jams or by using mechanical equipment to draw a channel water flow.

Pyrotechnical intervention is not always the best solution as ice blocks break rapidly, but the low river flow cannot transport the ice blocks and thus they remain in the main river bed. To drive them away the evacuated flow is increased if there is accumulation in the upstream.

\section{HYDRO-METEOROLOGICAL GENERAL CONDITIONS}

In January, 2017, the average liquid flow of the rivers in Romania was situated between 50 and $80 \%$ from annual average liquid flow, lower on rivers in basins such as: Iza, Tur, lower Someş, Crasna, Barcău, Crişuri, middle Mureş, Caraş, Nera, Cerna, Olt, Vedea, Argeş, Neajlov, Bârlad and on the tributaries of the Prut river (30-50\% from the monthly liquid flow) and higher on rivers in basins 
such as: Vişeu, Bistriţa, Moldova, Suceava, Trotuş, on rivers such as Olt, Putna and Prut (80-100\%). (See the Fig. 2 Romanian main rivers and water basin administrations).

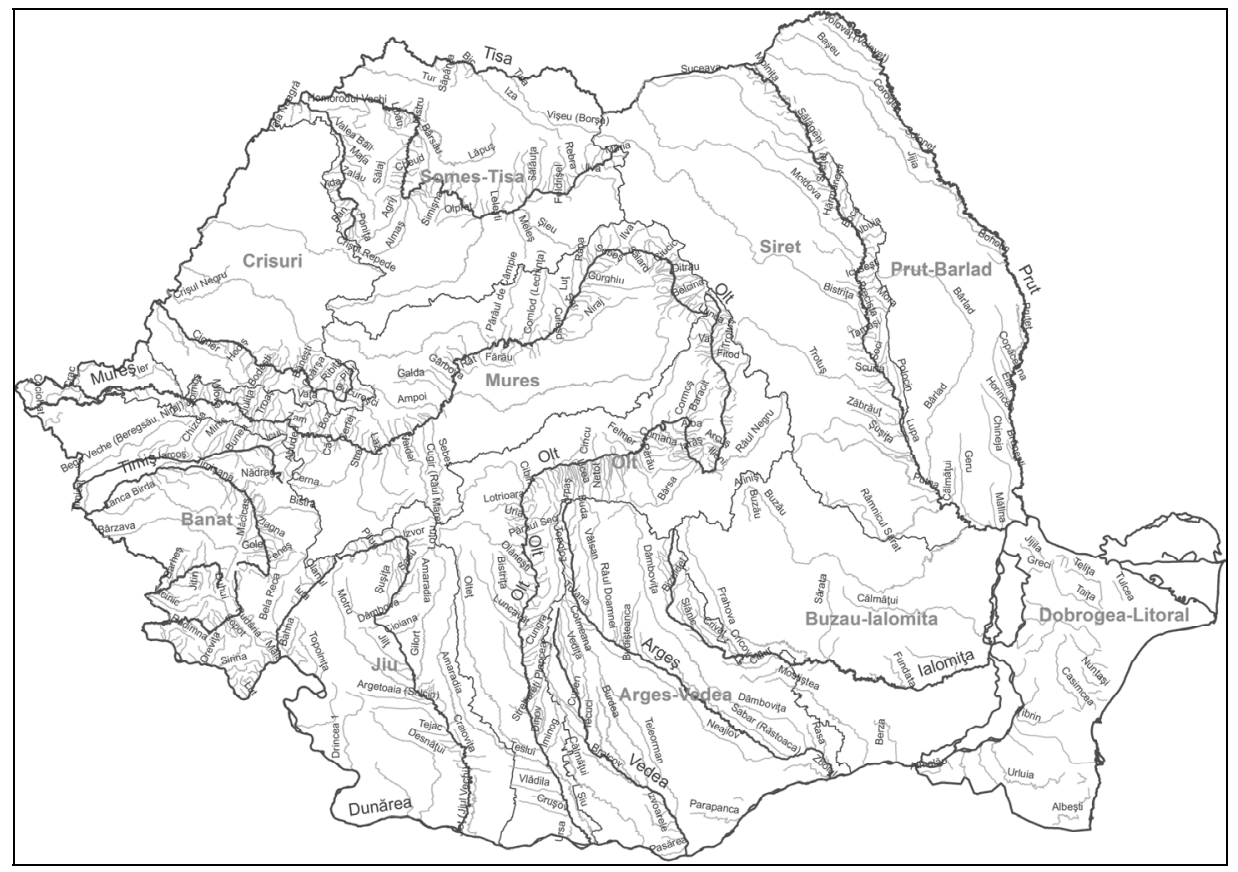

Fig.2. Romanian main rivers and water basin administrations

We should mention that daily values of river levels in January were significantly influenced by river winter phenomena present all month long.

In January, 2017, the Romanian river flows remains the same, excepting several periods: $5^{\text {th }}$ to $7^{\text {th }}$ January when it decreased on the rivers in Moldova, $12^{\text {th }}$ $15^{\text {th }}$ January when, there was a slight increase on the rivers in north-west and south-west of the country because of the water presence in snow layer and ice formations, and $16^{\text {th }}-20^{\text {th }}$ January when the flows were lower on the rivers in western part of Romania.

On the first day of January 2017, there was ice on the shores of most rivers, excepting the rivers in Banat and Crişana. There were ice bridges on rivers such as: Someșul Mare, Olt, Bistrița, Trotuș and Bârlad.

In the first half of January, different forms of ice were present on the rivers and at the end of the month ice bridges were found on most rivers.

During this interval, due to the river ice there were variations of level and flow on: Trotuş river at Lunca de Sus hydrometric station (h.s), Goleţ river at Goleț h.s., Firiza river at Firiza h.s., Bistra Mărului river at Poiana Mărului h.s. and Sibişel river at Sibişel h.s. There was ice blockages on: Someş river at Răstoci h.s., Someşul Mic river at Sălăţiu h.s., Mureş river at Radna h.s., Ialomiţa river at 
Târgovişte h.s., Bistriţa river at Frumosu h.s. and on Bistriţa river upstream Izvorul Muntelui reservoir.

In February 2017, the average liquid flow of rivers in Romania was over annual average on rivers like: Vişeu, Iza, Tur, Someş, Crasna, Barcău, Crişuri, Călmăţui, Siret, Mureş, Olt and on upper Prut. On the other rivers, average monthly flows were between 50 and $80 \%$ from the monthly average, higher (80$100 \%$ ) on rivers in Banat, on lower Mureş, on upper Jiu on mid and upper Ialomiţa and lower $(30-50 \%)$ on lower Olt and Vedea. On the first two days of February 2017 the river flows were quite normal excepting upper Crasna, Crişul Negru, Crişul Repede, Bega and Timiş where they were higher due to beacause of the water derived from the thick ice and from the consistent snow layer. During this interval, Tur river was over flood level in Negreşti Oaş because of the dislocation of the ice upstream.

During the period $3^{\text {rd }}-6^{\text {th }}$ of February the river flows were high due to heavy rainfall and the melted ice. In the north-west of the country rising levels could be found on rivers such as: Someșul Mare, Tisa, Iza, Ruscova, Tur, Someș, Lăpuș, Crişul Negru and Crișul Alb.

Ice formations were present on the first day of February, 2017 on most rivers in basins like: Bega, Timiş, Bârzava, Caraș, Nera, Cerna, Argeș, Buzău, lower Mureș (ice on shores).

On Bistriţa river, upstream of Izvorul Muntelui reservoir, 0,2 - 4,5 m thick ice layer was present on $12,9 \mathrm{~km}$.

Beginning with $2^{\text {nd }}$ February until $8^{\text {th }}$ of February ice started to melt mostly on western rivers leading to variations in river flows. Under the circumstances, the daily river levels in north, west and centre of Romania were influenced by ice. From $9^{\text {th }}$ to $13^{\text {th }}$ of February ice layer was increasing on rivers in the south, east and central part of the country, ice bridges being found on rivers such as: Siret, Prut and upper Muress and ice on shores on the other rivers in Transilvania, Oltenia, Muntenia and Dobrogea.

From $14^{\text {th }}$ to $18^{\text {th }}$ of February ice formations were present as usual, in the days that followed, even decreasing and melting. At the end of the month it was present only on upper Suceava, Moldova, Bistriţa, Trotuş, Râmnicu Sărat, Buzău, Prut, Bârlad, Olt and Argeș rivers.

\section{General weather conditions in January and February 2017}

In January 2017, the average temperature was much lower than usual all around the country. Thus, the average temperature in the country, $-6^{\circ} \mathrm{C}$, was fifth lowest temperatures in January from 1961 till present. Rainfall was lower than usual in Banat, Crișana, Transilvania, northern Moldova and western Oltenia, higher than normal in the rest of Oltenia, southern Muntenia and Dobrogea, and normal in the rest of the country.

In February 2017, the average temperature was higher in Banat, Maramureș, most Transilvania and locally in Crișana, northern Oltenia and northwestern Muntenia, and normal in the rest of the country. Rainfall was higher in 
Maramureș, northern Crișana, eastern Muntenia, southern and eastern Moldova and Danube Delta, lower than normal in Banat, southern Transilvania, nord-western Moldova, south-western Muntenia and south-eastern Oltenia, and normal in the rest of the country.

\section{RIVER WINTER CONDITIONS MONITORING}

During river winter conditions Romanian Waters National Administration (RWNA) drew a daily map with the ice phenomena on the rivers inside the country (http://www.rowater.ro/Fenomene\%20de\%20iarn/Forms/AllItems.aspx).

The National Institute for Hydrology and Water Management (NHWM) did not issue in January any hydrologic warning and issued in February six warnings regarding rapid snow melting and risk of ice jams occurrence which can lead to level rising, even flooding in some areas.

In January and February 2017 Meteorological National Administration (www.meteoromania.ro) through its Regional Meteorological Centres (RMC) issued 500 nowcasting warnings 3 hours prior to these phenomena: Dobrogea -47 , Moldova -98 , Southern Transilvania - 62, Northern Transilvania - 60, BanatCrișana - 57, Oltenia - 63 and Muntenia - 113 .

\section{INTERVENTION FOR CREATING FLOW CONDITIONS ON RIVERS}

In this purpose the Water Management System Alba (WMS Alba - county unit of "Romanian Waters" National Administration) formed 5 intervention teams equipped with an excavator and two backhoes. WMS Alba participated in this operation together with the County Inspectorate for Emergency Situations Alba (CIES - County Civil Protection) and local authorities in several localities: Albac (3 blockages), Vadu Moţilor (2 blockages), Bistra (2 blockages), Avram Iancu (1 blockage), Vidra (1 blockage) and Baia de Arieş (1 blockage). After the rain stopped and the temperatures have dropped, WMS Alba raised the Arieş river flow in order to remove the ice and clean the minor riverbed in Bistra and Gârde localities.

From $3^{\text {rd }}$ to $5^{\text {th }}$ of February there was significant rainfall in Bistriţa-Năsăud county, reflected on the flow of: Rebra river at Rebrișoara hydrometric station (HS) 46.5 1/sqm, Someș river at Rodna HS 42 1/sqm; Anieș river at Anieş HS 35.8 1/sqm; Cormaia river at Sângeorz Băi HS 34.7 1/sqm; Ilva river at Lunca Ilvei pluviometric station 28.8 1/sqm; Leșu river at Leşu HS 24.0 1/sqm and Someș river at Valea Mare HS 22.4 1/sqm.

The heavy rainfall led to increasing river levels and to formations of ice movement, forming ice torrents and floods in different areas.

WMS Bistriţa-Năsăud and ale CIES Bistriţa-Năsăud intervention teams came to clear the river beds in Coşbuc on Sălăuţa river, Rebrişoara on Gersa, Rebra on Rebra, Maieru on Someş, Şanţ village Valea Mare on Someş. 
In Harghita county from $23^{\text {rd }}$ to $25^{\text {th }}$ of February intervention teams came to remove the ice.

In Miercurea Ciuc, the Water Management System Harghita and the local Emergency Situations Volunteers Service from Miercurea Ciuc town (ESVS) prepared 250 sand bags, 100 of which were used for the intervention in Şumuleu locality. A team from SC Harviz SA Miercurea Ciuc came to clear the draining system. The intervention team intervened with a backhoe to remove the ice in two localities situated in the northern part of Harghita county (Dăneşti and Cârța). The intervention team used also 150 sand bags to control leakage on slopes because of the river deposits in Frumoasa locality.

ESVS Sântimbru team came with 10 volunteers, a truck and a tractor with backhoe and used 50 sand bags to redirect the overflown water to Valea Mare river and removed an ice bridge to make more room for the water.

Military firefighters from CIES Harghita evacuated the water from yards and cellars in town and villages such as: Miercurea Ciuc, Șumuleu, Gheorgheni, Odorheiu Secuiesc, Topliţa, Lăzarea, Leliceni and Şoimeni.

From $7^{\text {th }}$ to $9^{\text {th }}$ of February 2017, heavy rainfall occurred in Hunedoara county. In Buceş village a backhoe removed the river deposits from the county road DJ 742A. Military firefighters from Brad evacuated the water in flooded cellars.

From $22^{\text {nd }}$ of February to $21^{\text {st }}$ of March, 2017, in Iasi county the rainfall was about $25 \mathrm{l} / \mathrm{sqm}$ in Şipote. There was no technical intervention.

From 22nd to 24th of February, 2017 in Maramureş county the rainfall connected with positive temperatures led to increasing of debits in rivers. The pyrotechnical teams took action in three locations: on Cavnic river in Lăschia, on Lăpuş /upstream Rogoz and on Iza at Oncești. WMS Maramureş together with CIES Maramureş and ESVS Vişeu de Sus worked on Vaser and Radeasa rivers, and in villages Lăpuş, Rogoz and Coruia on Lăpuş river, Ruscova on Ruscova, Vadu Izei on Mara, Ferești on Cosău, Seini on Seinel.

From $3^{\text {rd }}$ to $5^{\text {th }}$ of February, 2017 in Mureş county the rainfall fell across the thick layer of snow (20-30 cm). Most rainfall occured in Stânceni on Mureş river $48.2 \mathrm{l} / \mathrm{sqm}$ in three days. Significant rainfall was also observed in Glodeni on Mureş river 26.8 1/sqm and in Lăpuşna on Gurghiu river $21.6 \mathrm{l} / \mathrm{sqm}$. Mureş Water Management System intervened to break the ice bridges in Hodac, Lunca Bradului, Ciobotani, Stânceni, Văgani and Topliţa. Two vehicles were used together with staff from Topliţa and Gurghiu. CIES Mureş used a pyrotechnical team on the upper Mureş from Stânceni to Ciobotani. CIES and Water Basin Administration Mureş (WBA - Basin unit of Romanian Waters National Administration) monitored the upper Mureş river, Gurghiu river near Hodac and Ibăneşti.

Due to rainfall and high temperatures in Suceava county, snow melt and ice displacement occured on Bistriţa and Suceava rivers.

The heaviest rainfall on $4^{\text {th }}$ and $5^{\text {th }}$ of February, 2017 was recorded: in Coşna on Teşna river $28.1 \mathrm{l} / \mathrm{sqm}$; in Poiana Stampei on Dorna river $22.8 \mathrm{l} / \mathrm{sqm}$ and in Dorna Giumalău on Bistriţa river 17.3 1/sqm. 
On $4^{\text {th }}$ February 2017 on the junction of Dorna and Bistriţa rivers 3-4 metres high river deposits pushed the ice over the side dams.

From $4^{\text {th }}$ to $6^{\text {th }}$ of February, 2017, the intervention team in Câmpulung Moldovenesc together with ESVS Vatra Dornei used 2700 sand bags to protect the households in Vatra Dornei. They used two special trucks and three pumps.

On the February $4^{\text {th }}, 2017$ Vatra Dornei brigade, part of CIES Suceava, removed the water from yards. On the February $5^{\text {th }}, 2017$, the Suceava county prefect commanded the forming of an operational team to monitor the ice torrents formed on Bistriţa river in Vatra Dornei and decided to detonate the ice blocks. As more detonations were necessary, CIES Suceava asked for CIES Botoşani and CIES Bacău's pyrotechnical help. CIES Suceava performed 5 detonation actions.

On the February $7^{\text {th }}, 2017$, pyrotechnical teams from CIES Suceava, CIES, Botoşani and CIES Bacău performed 7 detonation actions in Vatra Dornei, and 10 on Bistriţa river bed.

From $5^{\text {th }}$ to $7^{\text {th }}$ of February, 2017 teams from CIES Suceava evacuated the water from yards and flooded cellars.

As Bistriţa river flow was low, ice blocks remained in the river bed to prevent future floods. Later on, there was decided to remove the ice from Bistriţa river bed.

Two Hitachi long arm excavators were used to remove the ice. Technical assistance and coordination was done by Head of Hydraulic Works Operating Service WBA Siret Bacău together with its colleague from WMS Suceava together with the Head of Câmpulung Moldovenesc town operation team.

From $14^{\text {th }}$ to $23^{\text {rd }}$ February 2017 two long arm excavators, one short arm excavator, one bulldozer, two pippers and a truck were used to remove the ice.

Manual clearing was done on $3400 \mathrm{sqm} .17120 \mathrm{~m}^{3}$ of ice were dislocated and pushed onto 90 metres.

In Braşov county an ice block formed on Homorodul Mare river near Rupea hydrometric station on $7^{\text {th }}$ February 2017. Another ice block formed in Ungra. To clear the river bed, 12 workers used axes and crowbars. The intervention took 4 hours.

On $9^{\text {th }}$ of February 2017 upstream the bridge on the national road DN 7D connecting DN 7 A with Câinenii Mici village there were observed $1 \mathrm{~km}$ long and $80 \mathrm{~m}$ wide ice blocks pressing the shores and the bridge, thus endangering the bridge.

Somewhere downstream, 4,5 km away, there is the Robești hydropower plant on which an ice field took shape near the the bridges abutment.

To destroy the ice field CIES Vâlcea and CIES Sibiu intervened with pyrotechnical teams.

In 11 towns and villages pyrotechnical teams participated in operations. In other 48 villages, mechanical interventions took place. In other 15 water was evacuated from households. Damages were reported in 73 towns and villages.

\section{RECORDED DAMAGES IN JANUARY AND FEBRUARY, 2017}

In January damages were reported only Giurgiu county, where a consistent snow layer was observed. In 12 villages, the damages rose to 1.76 million lei. 
In February 11 counties were affected: Alba, Bistriţa-Năsăud, Botoşani, Caraş-Severin, Harghita, Hunedoara, Iaşi, Maramureş, Mureş Suceava and Vrancea with damages up to 12.941 million lei. The most affected county was BistriţaNăsăud, followed by Maramureş, Mureş and the least affected Hunedoara. In Bistriţa-Năsăud, a recently finalised investment on Someşul Mare river was affected at Cociu, where damage evaluation commission did not validate the damages. The investment is said to be worth around 7 million euro, and the declared damages being around 4 million euro.

The distribution of the affected localities (in red) during winter phenomena due to ice formations is shown in the figure nr. 3 .

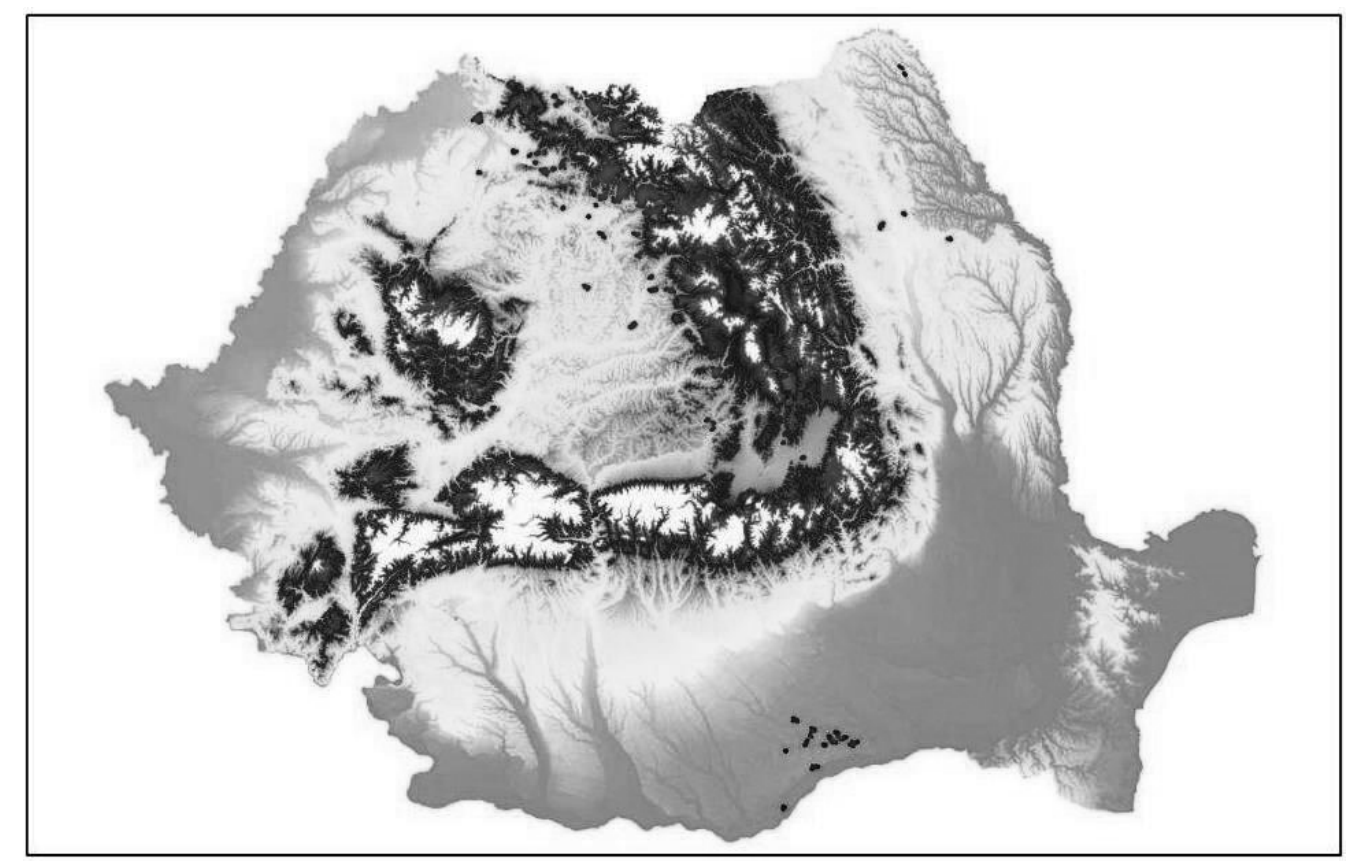

Fig. 3 Affected localities by Winter phenomena in January-February 2017

\section{CONCLUSIONS}

It is necessary that we improve the flood protection plans with specific ice formations response procedures.

The cooperation among Romanian Waters National Administration, County Inspectorates for Emergency Situations and Local Committee for Emergency Situations teams was strong, close and fruitful.

Interventions were fast. Help sometimes came from neighbouring counties.

Pyrotechnical teams from Botoşani and Bacău offered to help at the interventions in Suceava and in Vâlcea county, additional teams from Sibiu intervened together with local ones. 
As the operations were fast, the damages done by overflowing waters were minimum and in Vâlcea and Braşov counties there was no damage.

$17120 \mathrm{~m}^{3}$ of ice were dislocated from Bistriţa river bed around Vatra Dornei. This area is hit annually by ice due to the particular phenomenon appearing here on the Bistrita River upstream of Izvorul Muntelui reservoir - climate inversion and has some distinct characteristics from what is known from the literature and from the history of the lakes on other rivers in the country.

In January, damage was done in Giurgiu county due to snow and wind.

In February, most damage was done in Bistriţa-Năsăud, Mureş and the least important in Hunedoara.

Pyrotechnical intervention helped to remove thaws and reduce damage, sometimes manual intervention for ice breaking seems to be more appropriate, but when water level and river flow are low, dislocated ice blocks cannot be carried away. Therefore, removing them from river beds is necessary.

There were no major problems as the snow layer was not significant in February. Neither was rainfall so interventions occurred without impediments.

\section{R E F E R E N C E S}

1. Mustăţea, A. (2005), Exceptional floods on Romanian territory. Origins and effects, National Institute of Hydrology and Water Management Publishing House, Bucharest.

2. Pişota, I., (1995), Hydrology, Bucharest University Publishing House.

3. Stănescu, V. Al., Drobot, R. (2002), Nonstructural measures for floods management, HGA Publishing House, Bucharest.

4. Şelărescu, M., Podani, M., (1993), Flood defence, Technical Publishing House, Bucharest.

5. *** (2017), Interventions report Water Management System Braşov.

6. *** (2017), Interventions report Water Management System Vâlcea.

7. $* * *$ (2017), Report on the ice event 2017 in the Danube River Basin, International Commission for the Protection of the Danube River (www.icpdr.org).

8. *** Flood Defence Plans of the Someș-Tisa, Siret, Prut-Bârlad, Olt and Mureș hydrographic basins, Romanian Waters National Administration, Bucharest.

9. *** (2012), Governmental Order nr. 1422/192 for the approval of the General Rules for emergency situations management, generated by floods, meteorological dangerous phenomena, accidents at hydraulic structures, accidental pollution on watercourses and coastal zone of theBlack Sea.

10. http://www.hidro.ro

11. http://www.meteoromania.ro

12. http://www.rowater.ro/Fenomene $\% 20 \mathrm{de} \% 20 \mathrm{iarn} /$ Forms/AllItems.aspx 